\title{
Hemodiyaliz Hastalarında Cilt Sorunlarının Değerlendirilmesi
}

\author{
Assessment of Skin Manifestations in Patients \\ Undergoing Hemodialysis
}

\author{
Harun İN ${ }^{1}$, Nazan KILIÇ AKÇA ${ }^{2}$
}

${ }^{I}$ Uzman Hemşire- Sağllk Bilimleri Üniversitesi Erzurum Bölge Sağllk Uygulama ve Araştırma Merkezi, Erzurum, Türkiye

${ }^{2}$ Doç. Dr.- İzmir Bakırçay Üniversitesi Sağllk Bilimleri Fakültesi Hemşirelik Bölümü, İzmir, Türkiye

Geliş Tarihi / Received :

06 Ekim/Oct 2020

Kabul Tarihi / Accepted:

26 Ocak/Jan 2021

\section{İletişim yazarı / \\ Correspondence author}

Harun İN

E-posta: harun_in@outlook.com

\section{ORCID:}

Harun IN

0000-0002-5426-4429

Nazan KILIÇ AKÇA

0000-0001-6007-1896

\section{Özet}

Amaç: Hemodiyaliz hastalarında cilt problemleri sıklıkla ve değişik biçimlerde görülmektedir. Hastaların yaşam kalitesi üzerinde önemli etkisi olan çok sayıda cilt değişiklikleri ile kendini göstermektedir. Bu çalışma hemodiyaliz hastalarında çeşitli cilt problemlerinin sıklığını ve etkileyen faktörleri belirlemek amacıyla yapıldı.

Gereç ve Yöntemler: Araştırma tanımlayıcı ve kesitsel tiptedir. Araştırmanın örneklemini, dâhil edilme kriterlerine uyan ve araştırmaya katılmayı kabul eden 175 hasta oluşturdu. Araştırmanın verilerinin toplanmasında hasta tanıtım ve anket formu kullanıldı. Veriler araştırmacılar tarafindan yüz yüze görüşme tekniği ve fiziksel muayene yapılarak toplandi.

Bulgular: Hastaların \%73.1'inin hemodiyaliz tedavisine başladıktan sonra cilt sorunları yaşadığ 1 ve \%33.7'sinde ise beş cilt sorununun birlikte olduğu saptandı. Hastaların en sık yaşadığı cilt sorunlarına bakıldığında ise; sırasıyla \%65.1 ile kaşıntı, \%62.9 cilt kuruluğu, \%44 pigment değişikliği ve solukluk olarak saptandı.

Sonuç: Hemodiyaliz hastalarında cilt, saç ve tırnak değişikliklerinin yaygın olduğu saptandı. Hemodiyalizin süresi uzadıkça cilt problemleri artmaktadır. Sonuçlarımız, hemodiyaliz hastalarının morbiditesini azaltabilecek ve yaşam kalitesini önemli ölçüde artırabilecek bu dermatozların erken tanınması ve tedavisi için nefrologlar ve hemodiyaliz hemşiresi arasında ortak bir çaba gerektirmektedir.

Anahtar Kelimler: Kuruluk, Kaşıntı, Deri belirtileri, Hemodiyaliz. 


\begin{abstract}
Aim: Cutaneous alterations in patients with hemodialysis are frequently found but were variable. They present with multiple skin problems that have a significant impact on the quality of life of patients. The article aim to study the various cutaneous abnormalities and the factors affecting these manifestations in patients undergoing hemodialysis.
\end{abstract}

Material and Methods: This study is descriptive and cross-sectional. The sample of the study consisted of 175 patients who met the inclusion criteria and were accepted to participate in the study. Patient information and questionnaire forms were used in the data collection. The data were collected by the researchers with the face to face interview.

Results: It was found $73.1 \%$ of cases had at least one cutaneous finding attributable to hemodialysis patients and $33.7 \%$ of the patients had five skin problems together. The most common skin problems experienced by patients: Pruritus was observed in $65.1 \%$ of cases followed by xerosis $(62.9 \%)$, pallor and hyperpigmentation (44\%), skin lesion $(38.9 \%)$, nail change $(36.6 \%)$, and hair change $(48.0 \%)$.

Conclusion: Skin, hair and nail changes are common in hemodialysis patients. Dermatological manifestations increase with increasing duration of hemodialysis. Our observations necessitate a joint effort between and nephrologists, hemodialysis nurses, and dermatologists for the early recognition and management of these dermatoses which may reduce the morbidity and significantly improve the quality of life of hemodialysis patients.

Keywords: Xerozis, Pruritus, Cutaneous manifestations, Hemodialysis

\section{GíRiș}

Son dönem böbrek hastalığ1 (SDBH); birçok etiyolojik faktöre ilişkin olarak gelişebilen, nefronların ilerleyici ve geri dönüşümsüz kaybı ile karakterize patofizyolojik bir süreçtir (1). Amerika Birleşik Devletleri renal veri sistemine kayıtlı 40 farklı ülke vardır ve 2018 yılında son dönem böbrek yetmezliği insidansı en yüksek olan ülkeler Meksika, Tayvan, Macaristan ve Amerika'dır. Amerika'da 2018 yılında 131.636 kişiye son dönem böbrek yetmezliği tanıs1 konulmuştur. Amerika'da yaklaşı 856.444 kişi son dönem böbrek yetmezliği (SDBY) nedeniyle tedavi edilmektedir (2). Türk Nefroloji Derneği verilerine göre 2019 yılı sonu itibariyle ülkemizde SDBY'ye bağlı renal replasman tedavisi alan toplam yaklaşı 83.783 hasta bulunmakta ve bunların \%73.21'i hemodiyaliz (HD) tedavisi almaktadır. 2019 yılında ilk kez renal replasman tedavisi alan 12.518 hasta bildirilmiştir. 2019 y1lında renal replasman tedavisi gerektiren SDBY nokta prevalans1, milyon nüfus başına 1008 olarak saptanmıştır. Ülkemizin toplam sağlık bütçesinin \%5'ten fazlası bu hastaların tedavisi için harcanmaktadır (3).

Son dönem böbrek yetmezliğine bağlı belirti ve bulgular HD tedavisi ile kontrol altına alınırken, tedavi sürecine bağlı olarak vücutta farklı semptomlar da ortaya çıkabilmektedir. Bu semptomlardan bir kısmını ciltteki sorunlar oluşturmaktadır. Ciltte ortaya çıkan sorunlar inspeksiyon yöntemi ile rahatlıkla değerlendirilebilmektedir. Hemodiyaliz hastalarında üremik kaşıntı, kuruluk, solukluk, pigment değişikliği, deride peteşi ve purpuralar, kaşıntısız lezyonlar, kalsifikasyonlar, kateter çevresinde enfektif yapılar, fistül bulunan kolda hematom veya anevrizmalar, tırnaklarda çizgilenmeler, saç dökülmeleri ve incelmeleri sıklıkla görülmektedir $(1,4,5)$. Bazen de ciltteki ince değişiklikler altta yatan böbrek patolojisi hakkında ipucu olarak değerlendirilebilmektedir (6). Ciltte ortaya çıkan bir bulguyu SDBY veya tek başına HD ile ilişkilendirmek zordur (4). SDBY'de bu dermatolojik belirtilerin görülmesinin en temel sebepleri toksik maddelerin vücuttan uzaklaştırılamaması, hastaların kullandığ 
sistemidir. SDBY hastalarında cilt sorunlar1, genellikle glomerüler filtrasyon hızının 15 ml/dakikadan daha az olduğu son evredeki hastalarda görülmektedir $(7,8)$. Hemodiyaliz hastalarında görülen cilt sorunları fiziksel, psikososyal ve emosyonel olarak genel sağlik algilarında bozulmaya yol açabilmektedir. Ayrıca beden imajinda bozulma, benlik saygisında azalma, uyku bozuklukları ve yaşam kalitesinde azalmaya da neden olabilmektedir $(4,5)$. Bu hastalarda risklerin bilinmesi, değerlendirilmesi ve erken tanınması semptomları hafifletebilir ve morbiditeyi azaltabilir. Hemodiyaliz hemşireleri cilt sorunlarında doku bütünlügünde bozulma ve doku bütünlüğünde bozulma riski hemşirelik tanıları doğrultusunda hemşirelik süreci ve bütüncül bakım uygulamaktadırlar. Hemşirelerin hastanın HD merkezine kabul edilmesiyle birlikte cilt değerlendirmesi yapması, hastaya oluşabilecek değişiklikler konusunda eğitim vermesi ve HD süresince ayda bir cilt değerlendirmesi yapması önemlidir. $\mathrm{Bu}$ nedenle çalışma, HD hastalarında görülen cilt sorunlarının sıklığının ve bazı değişkenler (yaş, eğitim durumu, günlük su tüketimi, interdiyalitik kilo, Kt/V) ile cilt sorunları arasındaki ilişkinin belirlenmesi amacıyla yapılmıştır.

\section{GEREÇ VE YÖNTEMLER}

\section{Araştırmanın Tipi}

Araştırma tanımlayıcı ve kesitsel tiptedir.

\section{Araştırmanın Evreni ve Örneklemi}

Yozgat il merkezinde bulunan özel bir HD merkezi ( $\mathrm{n}=75$ hasta) ile Erzurum il merkezinde bulunan bir eğitim araştırma hastanesinin HD ünitesinde $(\mathrm{n}=150)$ tedavi alan 225 hasta araştırmanın evrenini oluşturdu. Veri toplama zamanı olarak ise cilt yapısı ve sağlı̆g mevsimsel değişikliklerden etkilendiği için mevsimsel olarak karasal iklimin görüldüğü illerde kış ayında yapıld1. Araştırmada herhangi bir örneklem seçme yöntemine gidilmemiş olup evrenin tamamı örnekleme dahil edildi. Araştırma 1 Ocak 2018-1 Mart 2018 tarihleri arasında araştırmaya gönüllü katılan ve araştırmaya dâhil edilme kriterlerine uyan 175 hasta ile tamamland.
Araştırmaya dâhil edilme kriterleri: altı aydır HD tedavisi gören, bilinci açık, görme-işitme kaybı nedeniyle iletişim engeli olmayan, algılama bozukluğu olmayan, anksiyete ve depresyon tedavisi almayan, kanser tanısı olmayan, daha önce deri hastalığ 1 (ürtiker, dermatit, sedef hastalığ1 gibi) tanısı almamış olan, araştırmaya katılmayı yazılı ve sözlü olarak kabul eden hastalar örnekleme dâhil edildi.

\section{Araştırmanın Veri Toplama Araçları}

Hasta tanıtım ve anket formu: Yazarlar tarafindan ilgili literatürler incelenerek oluşturulan hasta tanıtım formu; hastanın sosyodemografik özelliklerini içeren 8 soru, cilt yapısı ve kişisel hijyen alışkanlıklarını içeren 10 soru, SDBY ve HD süresi, hastanın diyete ve tedaviye uyumunu içeren 8 soru olmak üzere toplam 26 soru içermektedir (7-12). Yaşanan cilt sorunlarının varlığ1 araştırmacılar tarafindan fizik muayene ile, yaşanan semptomların şiddeti de hastalara sorularak subjektif olarak değerlendirilmiştir.

Kuruluk ……...................... Y Yok-Hafif-Orta-Ciddi

Kaşıntı................................. Yok-Hafif-Orta-Ciddi

Lezyon ............................... Yok-Hafif-Orta-Ciddi

Pigment değişikliği .............:Yok-Hafif-Orta-Ciddi

Solukluk............................: Yok-Hafif-Orta-Ciddi

Saç değişikliği......................:Yok-Hafif-Orta-Ciddi

Tırnak değişikliği................:Yok-Hafif-Orta-Ciddi

\section{Araştırma Verilerinin Toplanması}

Veri toplamaya başlamadan önce hastalara araştırmanın amacı açıklandı ve aydınlatılmış onamları sözlü ve yazılı olarak alındı. Çalışma sonucunu etkilememesi için hastalardan HD seansına gelmeden bir gün önce banyo yapmamaları ve nemlendirici kullanmamaları istendi. Hastaların sosyodemogrofik ve hastalık özellikleri hastaya sorularak, ilaçları ve laboratuvar bulguları hasta dosyas1 incelenerek ve cilt değerlendirmesi ise araştırmacı tarafindan hasta yatağında, paravanla hasta mahremiyeti sağlandıktan sonra; yüz, kol, el, karın sirt ve bacaklar inspeksiyon yöntemi ile değerlendirildi. Cilt sorunlarının şiddeti, diyaliz öncesi ve sonrası değerlendirilmesi hastanın sözel ifadesi ile belirlendi. Veri toplama formlarının 
doldurulması bir hasta için ortalama 20 dakika sürdü.

\section{Araştırmanın Etik Boyutu}

Araştırma öncesi Bozok Üniversitesi Rektörlüğü Klinik Araştırmalar Etik Kurulu'ndan araştırmanın uygulanabileceğine dair 2018-02-54 kayıt numarası ile etik kurul izni alındı. Araştırmanın yapıldığı kurumlardan, çalışmanın amaç ve kapsamını içeren bir bilgi formu ile yazılı başvuruda bulunularak yazılı izinler alındı. Araştırmada Helsinki Bildirgesi'nde yer alan etik ilkelere uyuldu, bireylere ait bilgilerin gizlilikleri korundu. Araştırmaya katılmaya gönüllülük ilkesine uyularak, katılımcılardan bilgilendirilmiş onam sözlü ve yazılı olarak alındıktan sonra uygulamaya başlandi.

\section{Verilerin Değerlendirilmesi}

Araştırmadan elde edilen veriler, SPSS 22.0 programına aktarılarak tanımlayıcı istatistikler (yüzdelik, ortalama, standart sapma) ve Spearman korelasyon analizi kullanılarak istatistiksel analizleri yapıldı.

\section{BULGULAR}

Hastaların yaș ortalaması $59.8 \pm 14$ (min-max:1893), \%55.4'ü erkek, \%81'i evli, \%46.3'ü ilkokul mezunu, \%96.6'sının çalışmadığ 1 \% \%65.2'sinin gelir durumunun orta seviyede olduğu ve \%49.8'inin il merkezinde yaşadığı saptandı (Tablo 1).

Hastaların SDBY nedenleri \%34.9'unda hipertansiyon, \%34.3'ünde diabetes mellitustu. Hastaların SDBY süresi $75.7 \pm 65.00$ ay ve HD süresi $54.9 \pm 52.12$ ay idi. Hastaların \%66'sının ikincil bir kronik hastalığı olduğu, kalp damar hastalıklarının (\%29.7) ilk sırada yer aldığı belirlendi.

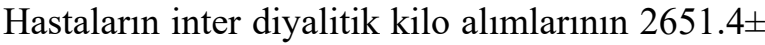
889.3 gr (min-max: 500-5000 gr) olduğu ve yar1dan fazlasinın (\%55.4) tıbbi beslenme tedavisine ve beşte birinin (\%20.5) ise ilaç tedavisine uyumsuz oldukları belirlendi (Tablo 2 ).
Tablo 1. Hastaların tanımlayıcı özelliklerine göre dağılımı $(\mathrm{n}=175)$

\begin{tabular}{|l|l|l|}
\hline Özellikler & $\mathbf{n}$ & \% \\
\hline Cinsiyet & \multicolumn{2}{|l|}{} \\
Kadın & 78 & \\
Erkek & 97 & 44.6 \\
\hline Yaş ortalaması (yıl) & \multicolumn{2}{|l|}{$59.8 \pm 14.1(18-93)$} \\
\hline Medeni durum & \multicolumn{2}{|l|}{} \\
Evli & 142 & 81.1 \\
Bekâr & 33 & 18.9 \\
\hline Öğrenim durumu & & \\
Okur-yazar değil & 61 & 34.9 \\
Okur-yazar & 17 & 9.7 \\
İlköğretim & 81 & 46.3 \\
Lise ve üzeri & 16 & 9.1 \\
\hline Çalışma durumu & \multicolumn{2}{|l}{} \\
Çalışan & 6 & 3.4 \\
Çalışmayan & 169 & 96.6 \\
\hline Gelir durumu & & \\
İyi & 27 & 15.4 \\
Orta & 114 & 65.2 \\
Kötü & 34 & 19.4 \\
\hline Yaşadığı Yer & & 29.1 \\
İl merkezi & 87 & \\
İlçe merkezi & 51 & \\
Köy & 37 & \\
\hline
\end{tabular}

Hastaların \%73.1'i HD tedavisine başladıktan sonra cilt sorunları yaşadığını, \%33.7'sinde beş cilt sorununun bir arada olduğu saptandı. Hastaların farklı şiddetlerde en sık yaşadığı cilt sorunlarına bakıldığında ise; \%62.9'unun cilt kuruluğu, \%65.1'nin kaşınt1, \%38.9'nun cilt lezyonları ve \%44.0'nün pigment (renk) değişikliği olduğu tespit edildi. Hastaların HD tedavisine başladıktan sonraki cilt değișiklikleri Tablo 3 'te verildi.

Hemodiyaliz süresi ile ciltte pigment değişikliği arasında pozitif yönde anlamlı bir ilişki saptandı $(\mathrm{p}<0.05) . \mathrm{Kt} / \mathrm{V}$ oranı ile ciltte görülen lezyonlar ve solukluk arasında negatif yönde anlamlı bir ilişki saptandı $(\mathrm{p}<0.01)$. Ayrıca hastaların yaşları arttıkça saç yapısı değişikliklerinin de arttığı tespit edildi. Hastaların hemodiyalize başladıktan sonra oluşan cilt değișiklikleri ve ilișkili faktörler Tablo 4'te verildi. 
Tablo 2. Hastaların hastalık ve tedaviye ilişkin özelliklere göre dağılımı $(n=175)$

\begin{tabular}{|l|c|c|}
\hline Özellikler & n & \% \\
\hline SDBY Tanı Süresi (Ay) & \multicolumn{2}{|c|}{$75.7 \pm 65.00(6-264)$} \\
\hline Hemodiyalize Girme Süresi (Ay) & \multicolumn{2}{|c|}{$54.9 \pm 52.12(6-264)$} \\
\hline SDBY Etiyolojisi & \multicolumn{2}{|c|}{} \\
Hipertansiyon & 61 & 34.9 \\
Diabetes Mellitus & 60 & 34.3 \\
Diğer Faktörler & 54 & 30,8 \\
\hline Eşlik Eden Kronik Hastalık Varlığı & \multicolumn{2}{|c|}{} \\
Evet & 98 & 66.0 \\
Hayır & 77 & 44.0 \\
\hline Kronik Hastalıklar & \multicolumn{2}{|c|}{} \\
Kalp damar hastalıkları & 52 & 29.7 \\
Solunum sistemi hastalıkları & 15 & 8.6 \\
Tiroid bezi hastalıkları & 11 & 6.3 \\
Üriner sistem hastalıkları & 8 & 4.6 \\
Sinir sistemi hastalıkları & 3 & 1.7 \\
Kas-iskelet sistemi hastalıkları & 3 & 1.7 \\
\hline İlaç Tedavisine Uyum & \multicolumn{2}{|c|}{} \\
Evet & 139 & 79.4 \\
Hayır & 36 & 20.6 \\
\hline Diyete Uyum & 97 & 54.6 \\
Evet & \multicolumn{2}{|c|}{} \\
Hayır & \multicolumn{2}{|c|}{} \\
\hline İnter Diyalitik Kilo (Gram) & \multicolumn{2}{|c|}{} \\
\hline
\end{tabular}

Tablo 3. Hastaların hemodiyalize başladıktan sonra oluşan cilt değişikliklerine göre dağılımı $(\mathrm{n}=175)$

\begin{tabular}{|l|c|c|c|c|}
\hline Cilt değişiklikleri & $\begin{array}{c}\text { Yok } \\
\mathbf{n}(\%)\end{array}$ & $\begin{array}{c}\text { Hafif } \\
\mathbf{n}(\%)\end{array}$ & $\begin{array}{c}\text { Orta } \\
\mathbf{n}(\%)\end{array}$ & $\begin{array}{c}\text { Ciddi } \\
\text { n (\%) }\end{array}$ \\
\hline Kuruluk & $65(37.1)$ & $36(20.6)$ & $49(28)$ & $25(14.3)$ \\
\hline Kaşıntı & $61(34.9)$ & $29(16.6)$ & $41(23.4)$ & $44(25.1)$ \\
\hline Ciltte lezyon & $107(61.1)$ & $56(32.1)$ & $9(5.1)$ & $3(1.7)$ \\
\hline Pigment değişikliği & $98(56)$ & $49(28)$ & $16(9.1)$ & $12(6.9)$ \\
\hline Solukluk & $98(56)$ & $48(27.4)$ & $23(13.1)$ & $6(3.5)$ \\
\hline Tırnak değişikliği & $111(63.4)$ & $49(28)$ & $12(6.9)$ & $3(1.7)$ \\
\hline Saç değişikliği & $91(52)$ & $56(32)$ & $17(9.7)$ & $11(6.3)$ \\
\hline $\begin{array}{l}\text { Post HD sonrası cilt } \\
\text { değişikliği }\end{array}$ & $128(73.1)$ & & $47(26.9)$ & \\
\hline
\end{tabular}


Tablo 4. Hastaların hemodiyalize başladıktan sonra oluşan cilt değişiklikleri ve ilişkili faktörler $(\mathrm{n}=175)$

\begin{tabular}{|l|c|c|c|c|c|c|}
\hline Cilt değişiklikleri & Yaş & $\begin{array}{c}\text { Eğitim } \\
\text { durumu }\end{array}$ & $\begin{array}{c}\text { Günlük su } \\
\text { tüketimi }\end{array}$ & $\begin{array}{c}\text { Diyaliz } \\
\text { süresi }\end{array}$ & $\begin{array}{c}\text { İnterdiyalitik } \\
\text { kilo }\end{array}$ & KtV \\
\hline Kuruluk & 0.087 & -0.006 & 0.012 & 0.106 & 0.025 & 0.071 \\
\hline Kaşıntı & 0.069 & -0.003 & -0.021 & 0.066 & -0.009 & 0.057 \\
\hline Ciltte Lezyon & 0.034 & 0.114 & 0.161 & 0.064 & 0.099 & $-\mathbf{0 . 3 8 9 * *}$ \\
\hline Pigment değişikliği & 0.023 & 0.079 & 0.145 & $\mathbf{0 . 2 7 4 *}$ & -0.040 & 0.149 \\
\hline Solukluk & -0.018 & 0.103 & 0.154 & 0.167 & 0.081 & $-\mathbf{0 . 2 3 5 *}$ \\
\hline Tirnak değişikliği & 0.103 & 0.113 & -0.023 & -0.080 & -0.199 & -0.058 \\
\hline Saç değişikliği & $\mathbf{0 . 1 3 4 *}$ & -0.099 & -0.014 & 0.127 & 0.106 & 0.027 \\
\hline
\end{tabular}

rs: Spearman korelasyon analizi

$* \mathrm{p}<0.05$

$* * \mathrm{p}<0.01$

\section{TARTIŞMA}

Deri vücudu ve iç organları dış ortamdaki zararlı mikroorganizmalardan, fiziksel ve kimyasal zararlılardan koruyan, yaşamsal önem taşıyan önemli bir savunma sistemidir ve derinin dışar1dan görünür şekli ise cilttir. Hemodiyaliz tedavisi alan hastaların tedavi süresince ciltte birçok semptom görülebilmektedir $(1,13)$. Bu araştırmada HD tedavisi alan hastaların yaklaşık dörtte üçü (\%73.1) HD tedavisi almaya başladıktan sonra cilt sorunları olduğunu belirtti. Literatürde SDBY olan hastaların; böbrek fonksiyon bozukluğuna ve HD tedavisine bağl1 \%50-100 arasında en az bir cilt sorununun olduğu belirtilmektedir (7-12). Araştırmamızda hastaların \%33.7'sinde beş cilt sorununun birlikte olduğu saptandi. Hastaların en sık yaşadığı cilt sorunlarına bakı1dığında ise; farklı şiddetlerde olmak üzere yaklaşık \%63'ünün cilt kuruluğu, \%65'inin kaşıntı, \%39'unun cilt lezyonları ve \%44'ünün pigment (renk) değişikliği saptandı. Raiesifar ve ark. (2019) hemodiyaliz hastalarında yaptı̆̆ araştırmada ise hastaların \%87'sinde solukluk, \%71'inde cilt kuruluğu, \%60'ında kaşıntı, \%46'sında hiperpigmentasyon, \%62'sinde cilt altı kanama belirtileri (peteşi ve purpura) ve \%81'inde ise tırnağa ilişkin belirtiler olduğu bildirilmiştir (22). Araştırmamızın sonuçları literatürle benzerdir. SDBY ve HD sürecine bağlı olarak oluşan kan biyokimyasındaki değişimler hastaların tedavi süreci içerisinde gelişen çeşitli cilt problemlerini yaşamasına neden olabilir. Düzenli ve doğru hemodiyaliz ise cilt değişikliklerini azaltabilecek- tir. Bu belirtilerin zamanında teşhis ve tedavisi, hastaların yaşam kalitesini arttırabilir ve sonraki endişeleri ortadan kaldırabilir.

Araştırmamızda HD tedavisi alan hastaların yarısından fazlasının HD'ye başladıktan sonra farklı şiddette cilt kuruluğu oluştuğu saptandı. Yapılan farklı çalışmalarda SDBY ve HD tedavi süresince cilt kuruluğu görülme sıklığ $1 \% 98$ (14), $\% 62.2$ (12) ve \%76.2 (15) olarak belirtilmektedir. Araştırma bulgularımız literatür bulguları ile uyumludur. Cilt dehidrasyonu, diüretikler, hipervitaminoz A, azalmış sebum/ter atılımı, değiştirilmiş cilt bariyeri ve yeterli cilt nemlendirici kullanmama, ayrıca dış etkenler de (güneş, toz, deterjanlar) belirgin derecede tahriş edici hale geldiğinde kuruluğa neden olabilmektedir (4). Bununla birlikte, çalışmamızın yapıldığı illerde hüküm süren karasal iklim de ek olarak cilt kuruluğuna etki eden bir faktör olabilir.

Hemodiyaliz tedavisi alan hastalarda en sık görülen diğer bir cilt bulgusu ise kaşıntıdır. Genelleştirilmiş veya lokalize, değişken yoğunluğa sahip epizodik veya sürekli kaşıntı SDBY'de sık görülür. $\mathrm{Bu}$ araştırmada hastaların $\% 65$ 'i çeşitli derecelerde kaşıntı yaşadığını ifade etti. Altınok Ersoy ve Akyar'ın çalışmasında (2019) HD hastalarında; \%86.7'sinde HD seansindan önce, $\%$ 72.9'unda HD sirasinda ve \%49.7'sinde ise HD'den sonra kaşıntı görüldüğü bildirilmiştir (16). Kılıç Akça ve Taşçı'nın (2014) üremik kaşıntı üzerine yaptıkları çalışmada; hemodiyaliz hastalarının \%75.5'inde kaşıntı görüldüğü bildirilmiştir (17). Asayesh ve ark.'nın (2019) 
2003 ve 2016 yılları arasında İran'da yapılan yedi çalışmada HD hastalarındaki dermatolojik bulguların meta-analizi sonucu İran'daki HD hastalarının kaşıntı prevalansını \%52.8 olarak saptanmıştır (18). Üremik kaşıntının patogenezi tam olarak anlaşılamamıştır ancak yoğunluğu, kuruluğun ciddiyeti ile doğru orantılıdır (17). Bu çalışmada da kuruluk ve kaşıntının doğru orantılı olduğu saptandı. Kılıç Akça ve Taşcı'nın çalışmasında (2014) cilt kuruluğu ile kaşıntı arasında önemli bir ilişki olduğu cilt kuruluğu arttıkça kaşıntının da arttığı belirtilmiştir (17).

Hemodiyaliz tedavisi alan hastalarda cilt rengi ile ilgili değişiklikler arasında solukluk, ciltte sararma, gri-kahverengi cilt ve ekimozlar bulunabilmektedir $(4,8,12)$. Araştırmada çeşitli derecelerde olmak üzere hastaların \%44'ünde pigmentasyon bozuklukları saptandı. Güder ve ark.'nın yaptığı çalışmada (2012) \%51 oranında pigmentasyon değişiklikleri olduğu belirtilmiştir (14). Sartika ve ark.'nın çalışmasında (2019) hemodiyaliz tedavisi alan böbrek yetmezliği hastalarının \%81.4'ünde hiperpigmentasyon görülmesine rağmen HD'ye girmeyen böbrek hastalarının \%37.2'sinde hiperpigmentasyon görüldüğü bildirilmiştir (23). Çalışmamızda HD hastalarında HD süresi artıkça ciltte pigmentasyon değişikliklerinin arttığı saptandi. Sonuçlarımız literatürdeki sonuçlarla benzer olduğu görülmektedir. SDBY ve HD bu değişim dermiste karotenoid ve nitrojen pigmentlerinin (ürokromlar) birikimine veya epidermis ve deri altı dokudaki lipokrom ve karotenoidlerin varlığı ile ilişkilendirilmektedir. Güneşe maruz kalan cilt bölgelerindeki yaygın hiperpigmentasyon, derinin bazal tabakasındaki melanin salınımının artmasına bağlanmaktadır (4). Tipik cilt rengi değerlendirmesinde, bir ten rengi tanıma işleminin doğru göz gözlemi ve 1 şık yoğunluğu gibi çevresel koşullar gerektirdiği unutulmamalıdır; bu nedenle, bir vakanın değerlendirilmesi yüksek derecede özen ve 1 şı gerektirmektedir.

Son dönem böbrek yetmezliğinin ilk başlayan ve ayırt edici özelliklerinden biri olan anemi nedeniyle deride ortaya çıkan solgunluk, hastaların \%64'ünde görülmektedir. Koyu tenli hastalarda solgunluk daha iyi ayırt edilebilmektedir $(8,15)$. Araştırmamızda hastalarda çeşitli derecelerde olmak üzere $\% 44$ ile ciltte solukluk ve ekimoz saptand1. Malkud ve ark.'nın (2020) HD hastalarında yaptıkları çalışmada hastaların \%46.6'sında ciltte solukluk bildirilmiştir. Ciltteki solukluğun nedeninin düşük hemoglobin seviyeleri olabileceği ifade edilmiştir(24). Bu çalışmada da hastaların Kt/V oranı düştükçe yani hastanın diyaliz yeterliliği azaldıkça ciltte görülen lezyon sayısının arttığı belirlendi. Hipervolemiden artan damar kırılganlığı ve trombosit işlev bozukluğu, diyaliz sırasında değişen üre seviyeleri, diyaliz yeterliliği ve heparin kullanımına bağlı lezyon ve ekimozlar görülebilmektedir. Ayrıca hastaların $\% 48$ 'inde saç değişikliği (saç tellerinde incelme ve dökülme) ve \%36.6'sında tırnak değişikliği saptand. Hemodiyaliz hastalarında azalmış sebum üretimi ve parathormon seviyeleri, anemi, son dönem böbrek yetmezliği/diyaliz stresi veya saç bakımını ihmal etmek vb. nedenlerle saçlarda değişiklikler ortaya çıkabilmektedir. Yaşla birlikte saçların yapısında değişiklikler ortaya çıkmaktadır. Ayrıca hastaların yaşları arttıkça saç yapısında değişikliğin de arttığı görülmektedir. Literatürde HD hastalarının \%35.2- \%56'sında tırnak değişikliği görüldüğü bildirilmiştir $(12,15$ 18). Maskey ve ark. (2020) yaptıkları araştırmada cilt bulgular1 arasında ikinci sırada (hastaların \%75'inde) tırnağa ilişkin belirtilerin saptandığ bildirilmiştir (25).

Çalışmamızda HD tedavisi alan hemen hemen tüm hastalarda en az bir cilt sorunu olduğu; en yaygın görülen cilt problemlerinin kuruluk ve kaşıntı olduğu saptandı. Bununla birlikte, çeşitli çalışmalarda cilt bulgularının görülme sıklığ farklı şekilde bildirilmiştir. Bu farklılıkların, bireysel, çevresel ve kültürel faktörlerden kaynaklanabileceği düşünülmüştür.

\section{Sinırlılıklar}

Çalışmada cilt sorunlarının görülme durumları ile HD'de kullanılan membran (türü, teknik özellikleri) ve hasta serum kan sonuçları (hemoglobin, bilirubin, üre, kreatin, vb) ile karşılaştırma yapılmamıştır. Ayrıca fizik muayenede cildin değerlendirilmesi için inspeksiyon yöntemine yardımcı olmak amacı ile ışı kaynağı kullanılmamasıdır. 


\section{SONUÇ ve ÖNERÍLER}

$\mathrm{Bu}$ çalışmada HD tedavisi alan hastalarda kuruluk, kaşıntı, cilt solukluğu/pigment değişiklikleri ve tırnak değişiklikleri gibi mukokutanöz değiş̧iklikler oluştuğu belirlendi. HD hastalarının ciltlerine ilişkin bulguların prevalansının yüksek olduğu, hastaların HD yeterliliği azaldıkça ciltte görülen lezyon sayısının arttığı belirlendi. Cilt değişikliklerine ilişkin literatürdeki bazı farklılıklar cilt kuruluğu, mevsimsel ve çevresel koşullardan, soğuk ve kuru hava, nem, sıcaklık, cilt bakım özellikleri, hijyen alışkanlıkları ve coğrafi konumdan etkilenebildiği için çalışmanın yapıldığı, yer-zaman ve hasta özellikleri ve HD tedavisi ve tedavi rejimine uyumdan etkilenebilir. SDBY hastalarında cilt değişikliklerini azaltmak için klinik farkındalığın arttırılması ve erken teşhis ve tedavi ile birlikte önleyici stratejilerin uygulanması gereklidir. Günlük aktivitelerinin sürdürülebilmesi için HD hastalarında görülen cilt bulgularını ve genel sağlıkla ilgili belirtilerin birlikte yönetilmesi gerekmektedir. SDBY olan hastalarda, cilt problemlerinin nedenlerini ve buna bağlı yaşadıkları sorunlar için kalitatif çalışmalar yapılması önerilebilir.

\section{Teşekkür/ Acknowledgements}

\section{Finansal destek/ Financial support}

Yazarlar herhangi bir finansal destek beyan etmemişlerdir.

\section{Çıkar çatışması/ Conflict of interest}

Yazarlar herhangi bir çıkar çatışması olmadığını beyan etmişlerdir.

\section{Hakemlik/ Reviewing process}

Çift kör hakemlik süreçleri uygulanmıştır.

\section{Yazarlık katkısı/ Author contribution}

Çalışma fikri ve tasarımı: HI, NKA

Veri toplama ve analizi: HI, NKA

Makalenin hazırlanması: Hİ, NKA

Eleştirel inceleme: NKA, HI

\section{Kaynaklar}

1. Karadakovan A, Eti Aslan F. Dâhili ve Cerrahi Hastalıklarda Bakım. Genişletilmiş 3. Baskı. Ankara; Akademisyen Kitabevi; 2014.

2. USRDS (2020). USRDS Annual Data Report: Epidemiology of kidney disease in the United States. National Institutes of Health. https://adr.usrds.org/2020. Erişim Tarihi: 25.01.2021

3. Süleymanlar G, Ateş K, Seyahi, N. (2020). Türkiyede Nefroloji-Diyaliz ve Transplantasyon Registry 2019. Retrieved from Ankara: http://www.nefroloji.org.tr/folders/file/registry_2019.pdf. Erişim Tarihi:25.01.2021

4. Kılıç Akça N. Hemodiyaliz Hastasında Cilt Sorunları ve Bakımı. Türk Nefroloji, Diyaliz ve .Transplantasyon .Dergisi 2019;14(1):26-32.

5. Dedeli Çaydan Ö, Çınar Pakyüz S. Hemodiyalizin kronik komplikasyonları ve bakım. Nefroloji Hemşireliği Dergisi 2016;1(1):60-72.

6. Ghunawat S, Barman KD, Sarkar R, Garg VK, Alhawat RS. Spectrum of dermatological manifestations in patients with chronic kidney failure. MAMC Journal of Medical Sciences 2015;1(2):96-100.

7. Sanai M, Aman S, Nadeem M, Muhammad AH. Dermatologic manifestations in patients of renal disease on hemodialysis. Journal of Pakistan Association of Dermatology 2010;20(1):163-8.

8. Udayakumar P, Balasubramanian S, Ramalingam K, Lakshmi C, Srinivas C, Mathew AC. Cutaneous manifestations in patients with chronic renal failure on hemodialysis. Indian Journal of Dermatology, Venereology, and Leprology 2006;2(72):119-25.

9. Coulibaly G, Korsaga-Somé N, Yongué Fomena DF, Nagalo Y, Roger Karambiri A, Bassolet A, et al. Les manifestations cutanées chez les patients hémodialysés chroniques dans un pays en voie de développement. Pan African Medical Journal 2016;24(110):2-9.

10. Hajheydari Z, Makhlough A. Cutaneous and mucosal manifestations in patients on maintenance hemodialysis. Iranian Journal of Kidney Diseases 2008;2(2):86-90.

11. Uphar G, Prasad B. N. R. Cutaneous manıfestations in patıents undergoing haemodialysis for end stage renal disease. J of Evolution of Med and Dent Sci 2015:5872-6. 
12. Baghel N, Awasthi S, Sweta SK. Cutaneous manifestations in patients with chronic kidney diseases on haemodialysis. International Journal of Research in Medical Sciences 2017;5(4):1673-8.

13. Madiha S, Shahbaz A, Nadeem M, Kazmi AH. Dermatologic manifestations in patients of renal disease on hemodialysis. Journal of Pakistan Association of Dermatologists 2010;20(3):163-8.

14. Güder S, Karaca Ş, Kulaç M, Yüksel Ş, Güder H. Afyonkarahisar ve çevresinde diyalize giren kronik böbrek yetmezlikli hastalardaki deri bulguları. Türkderm 2012;46(4):181-5.

15. S. Rashpa R, K. Mahajan V, Kumar P, Mehta KS, Chauhan PS, Rawat R, et al. Mucocutaneous manifestations in patients with chronic kidney disease:A Cross-sectional Study. Indian Dermatology Online Journal 2018;9(1):20-6.

16. Altınok Ersoy N, Akyar İ. Multidimensional pruritus assessment in hemodialysis patients. BMC Nephrology 2019;20(42):2-7.

17. Kılıç Akça N, Taşçı S. An ımportant problem among hemodialysis patients: uremic pruritus and affecting factors. Türk Nefroloji Diyaliz ve Transplantasyon Dergisi 2014;23(3):210-2016.

18. Asayesh H, Peykari N, Pavaresh-Masoud M, Esmaeili Abdar M, Tajbakhsh R, Mojtaba Mousavi S, et al. Dermatological manifestations in hemodialysis patients in Iran: A systematic review and meta-analysis. J Cosmet Dermatol 2019;18(1):204-11.

19. Mirza R, Wahid Z, Talat H. Dermatological manifestations in chronic renal failure dermatological manifestations in chronic renal failure. Liaquat University of Medical \& Health Science 2012;11(1):24-8.

20. Levillard DT, Kambil SM. Cutaneous manifestations in chronic renal disease-an observational study of skin changes, new findings, their association with hemodialysis, and their correlation with severity of CKD. International Journal of Scientific and Research Publications 2015;5(3):727-36.

21. Salhab MM, Shalhub S, Morgan MB. A current review of the cutaneous manifestations of renal disease. Journal of Cutaneous Pathology. Journal of cutaneous pathology 2003;30(9):527-38.

22. Raiesifar Z, Tahery, N, Shirzadegan R, Baraz, S, Darabiyan P, Raiesifar A. Assessment of skin manifestations in endstage renal disease patients undergoing hemodialysis in Shahid Beheshti Hospital of Abadan and Vali-e-Asr Hospital of Khorramshahr. Jundishapur Journal of Chronic Disease Care 2019; 8(1):1-5.

23. Sartika D, Putra I. B, Yosi A. Profile of Skin manifestations in chronic kidney failure patients with hemodialysis and non-hemodialysis in universitas Sumatera Utara Hospital Medan. International Journal of Scientific and Research Publications. 2019;9(10):497-500.

24. Malkud S, Dyavannanavar V, Varala S. Cutaneous manifestations in patients with chronic kidney disease on hemodialysis. Journal of Pakistan Association of Dermatology. 2020;30(3), 490-496.

25. Maskey A, Kumar A, Shrestha R. Study of Cutaneous Manifestations in End Stage Kidney Disease Undergoing Hemodialysis. Nepal Journal of Dermatology, Venereology \& Leprology 2020;18(1):37-43. 